\title{
SZEXUÁLIS KULTÚRA VIZSGÁLATA MISKOLCI KÖZÉPISKOLÁS DIÁKOK KÖRÉBEN
}

\author{
Kiss-Kondás Dóra \\ mestertanár, Miskolci Egyetem, Alkalmazott Egészségtudományok Intézete, Fizioterápiás Intézeti Tanszék \\ 3515 Miskolc, Miskolc-Egyetemváros, e-mail: efkdora@uni-miskolc.hu
}

\begin{abstract}
Absztrakt
A családalapitás és az azt megelözö életesemények időzitése változást mutat a korábbi évtizedekhez képest. A szexuális élet kezdete a középiskolai évek idejére tehetö. Az oktatási intézmények jelentös szerepet töltenek be az ismeretátadásban, azonban a család szerepe sem elhanyagolható. A kutatás célja a szexuális magatartás és tájékozottság felmérése, valamint annak megállapitása volt, hogy hol tudnak hatékonyan bekapcsolódni a szexuális egészségnevelés folyamatába az egészségügyi tanár mesterdiplomát szerzettek. A 150 miskolci középiskolás diák által kitöltött kérdöivek elemzése mentén látható, hogy a vizsgált diákok nagyobb része szexuálisan még nem aktív. A védekezéssel összefüggö ismereteik többségében megfelelöek. A család szerepe az információátadásban viszont csekély. A vizsgálat feltárta a beavatkozás optimális idejét és bizonyos ismeretbéli hiányosságokra is rámutatott, amelyek segíthetik a szexuális nevelés tervezését.
\end{abstract}

Kulcsszavak: szexualitás, középiskola, tájékozottság, család

\begin{abstract}
Timing of starting a family and the life events before that have changed since the last decades. First sexual experiences happen at the beginning of high school years. Educational institutions have a significant role in sexual information, but the importance of family support is remarkable as well. The research aimed to examine the sexual behaviour and knowledge of high school students, then to find out where teachers of healthcare can join effectively in the process of sexual health education. According to the results of 150 pieces of questionnaires, the majority of the examined students are not sexually active. Their knowledge about sexual protection is mostly decent. The role of parents in giving information about sexual life lag behind. The results showed the optimal timing of early education and some deficiency in knowledge, so this information could be useful in planning of sexual education.
\end{abstract}

Keywords: sexuality, high school, knowledge, family

\section{Bevezetés}

A demográfiai adatok alapján hazánk népessége csökkenő tendenciát mutat [1][2]. A népességi helyzet alakulását befolyásoló családalapítás és gyermekvállalás későbbi életkorra tolódik, a férfiaknál nagyobbrészt a 30-as évek elején, a nőknél a 20-as évek végén valósul meg [3]. A szexuális aktivitás viszont a fiatalok jelentős részénél már a középiskolai tanulmányok ideje alatt megkezdődik, a 15 éves korosztály közel fele túl van az első élményszerzésén. Az első nemi kapcsolat létesítése 16-18 éves korig a mai fiataloknál kétszer-háromszor gyakoribb, mint az utóbbi két évtized tizenéveseinél. A házasság előtti szexuális élet pedig manapság már természetes [4]. Pécsi középiskolás fiatalok 
körében végzett kutatás alapján a szexuális kapcsolat létesítésének módjáról átlagosan 11,39 évesen hallottak először a megkérdezett fiatalok, $68 \%$-uk élt is már nemi életet. Az első élményszerzés átlag életkora 14,77 év volt [5].

A nemi élet kezdete és az első gyermek születése között eltelt idő megközelítőleg 10-15 év. Erre az időszakra kell biztosítani a megfelelő fogamzásgátlási módszereket, melynek első lépése a megfelelő tudás kialakítása az adott témában. Az extrémen meghosszabbodott védekezésre szükséges időszak miatt fontos, hogy a fiatalok a kellő időben szerezzenek releváns ismereteket az egészséges nemi élet terén, illetve, hogy az egyén megtalálja a számára legelőnyösebb terhességmegelőzési módszert [4].

Az együttélés nélküli párkapcsolatok 20 éves kor előtt a fiatalok jelentős részét érintik [6]. Az egészséges szexuális magatartással kapcsolatos ismeretek viszont hiányosak lehetnek, ennek köszönhetően az első szexuális élmények előre nem tervezett módon történhetnek, így gyakoribb lehet a védekezés mellőzése is. A tudatosan készülők aránya csekély a fiatalok körében [4].

A szexuális nevelés célja a szexuális egészség kialakítása, amely a megfelelő nemi kultúra megismertetése mentén valósul meg [7]. A család szerepe ezesetben sem elhanyagolható jelentőségü, az otthoni felvilágosításban részesülő fiatalok tájékozottsága kiemelkedően jobb. A leghatékonyabb azonban a formális, iskolai keretek közötti és a szülő által biztosított szexuális nevelés együttese koherens értékközvetítés mentén [5][7].

\section{Kutatási cél}

A kutatási cél a miskolci középfokú intézményben tanuló diákok szexuális magatartásának és ismereteinek, valamint a családi környezet előbbiekre gyakorolt hatásának vizsgálata volt. Ezen felül arra kerestük a választ, hogy a 2016 óta egészségügyi tanár képzésben tanuló szakembereknek hol érdemes bekapcsolódniuk a szexuális nevelés folyamatába, milyen lépéseket tehetnek a diákok megfelelő szemléletmódjának kialakítása érdekében.

\section{Anyag és módszer}

A keresztmetszeti vizsgálat során a minta kiválasztásakor feltételként szerepelt a miskolci székhelyü középfokú intézményben tanulói jogviszony fennállása, illetve a 15-17 év közötti életkor. A gimnáziumi és szakgimnáziumi képzésben tanulók szülői beleegyezés után, önként vállalták a kutatásban való részvételt.

Az adatgyüjtés kvantitatív Survey-módszerrel valósult meg. Az anonim módon kitölthetö, papíralapú kérdőívek kérdéscsoportjai a demográfiai adatok után kitértek a családi háttérre, a partnerkapcsolatokra, a szerelemre és a nemi életre. Utóbbi esetén feltárták a saját élmények, a vélemények és a szerzett ismeretek körét, illetve a szülők szerepét a tájékoztatásban. A kérdések forrása részben a 'Nyíregyháza Ifjúsága 2015' kutatásban alkalmazott kérdéssor volt, illetve saját összeállítású kérdéscsoportok is megjelentek a kérdőívben [8]. Az adatfelvétel 2018-ban történt. A vizsgálat során 150 diáktól érkezett vissza értékelhetően kitöltött kérdőív.

Az adatok rögzítése, illetve az eredmények értékelése Excel 2016 és SPSS 22-es statisztikai programmal valósult meg. A leíró statisztikai számítások mellett az elemzés részeként t-próba ( $\mathrm{p}<0,05)$, Khí-négyzet próba és kereszttábla elemzés történt. 


\section{Eredmények}

\subsection{A vizsgálati minta bemutatása}

150 diák vett részt a kutatásban, 72 fiú (48\%) és 78 lány (52\%) alkotta a vizsgálati mintát. A résztvevők átlagéletkora a vizsgálat idején 16,57 év volt $(\mathrm{SD}: 0,572)$. A fiúk $(\mathrm{n}=72)$ életkorának átlaga 16,69 év, a lányoké ( $\mathrm{n}=78$ ) 16,46 év volt. A családi háttérre vonatkozó kérdések elemzése során kiderült, hogy 149 fö saját családjában, míg 1 diák nevelöcsaládban élt. A fiatalok 94,67\%-a együtt élt édesanyjával, azonban az édesapák csak az esetek 66\%-ában laktak egy háztartásban gyermekükkel. A szülök válása megközelítőleg minden harmadik családban előfordult $(32,21)(\mathrm{n}=149)$.

A család anyagi helyzetének szubjektív megítélése nagyobb számban kedvező volt, 66 fö gondok nélkül, 57 fő beosztással élt meg jól családjával, tehát a részt vevő tanulók $82 \%$-a anyagilag stabil helyzetủ volt. Nehéz helyzetben a 150 kitöltő közül csupán 19 fő élt. Súlyos anyagi veszteség vagy munkahely elvesztése többségében nem terhelte a családokat (73\%).

\subsection{Szexuális magatartás}

A kitöltés idején a fiatalok csupán 28,19\%-ának volt párkapcsolata (n=149). A kitöltők 67,57\%-a azonban arról nyilatkozott, hogy korábban volt már egy vagy akár több kapcsolata is $(\mathrm{n}=148)$.

A vizsgált fiatalok véleménye szerint 14 éves kor felett, azon belül is 64\% szerint 17-18 éves korban optimális a szexuális élet megkezdése $(\mathrm{n}=149)$. Az idealizált kezdet után a diákok által megélt első alkalomra, a szüzesség elvesztésének tényleges idejére is irányult kérdés. A diákok $60,54 \%$-a nyilatkozott arról, hogy még nem kezdte meg nemi életét. A fiatalok 2,04\%-a 13 éves kora elött, 15,65\%-uk 14-15 évesen, míg 21,77\% 16-17 évesen veszítette el szüzességét ( $\mathrm{n}=147$ ).

35 fö rendelkezett állandó szexuális partnerrel, 4 fö egy időben több zajló kapcsolatról is beszámolt. A múltra tekintve nagyobb arányban egy-három partnert említettek a fiatalok. A heti gyakoriság szerint aktív szexuális életet 24 fö (16,21\%) élt a megkérdezés idején, 29 fő $(19,59 \%)$ ritkábban tette ugyanezt. Egyszeri szexuális kapcsolatot a nemek viszonylatában hasonló arányban tapasztaltak a megkérdezettek (7 lány 5 fiú), de többszöri „egyéjszakás viszonyt” csak fiúk létesítettek $(n=148)$.

A szexuális kapcsolatot már tapasztaltak közül 70\% mindig, 21\% időnként tesz lépéseket a védekezés érdekében, közel $9 \%$ viszont nem szokott védekezni az együttlétek során.

A szakirodalom szerint az alacsonyabb társadalmi rétegekhez tartozók korábbi életkorban vállalnak gyermeket, így feltehetően hamarabb is kezdik nemi életüket [6]. A vizsgált diákok esetén, a statisztikai számítások szerint azonban nem igazolódott, hogy a nehezebb körülmények között élő családok gyermekei hamarabb kerültek szexuális kapcsolatba. Az elváltak gyermekei között szinte azonos volt az arány a szexuális együttlétet tapasztaltak és nem tapasztaltak között, így a vizsgált minta alapján az sem bizonyosodott be, hogy a szülők válása, az otthoni negatív hatásoktól menekülés okán hamarabb bonyolódtak volna nemi kapcsolatba az ezt megélt diákok [9].

\subsection{Szexualitással kapcsolatos tájékozottság}

\subsubsection{A nemi élettel kapcsolatos ismeretek forrása}

A vizsgált középiskolások több mint fele (53,38\%) 10-12 éves korában hallott először a szexuális kapcsolat létesítésének módjáról, a csoport közel negyede (22,3\%) azonban már 10 éves kora előtt szerzett információt ezzel kapcsolatban $(\mathrm{n}=148)$. Az első beszélgetések csak a csoport kevesebb, mint negyedénél zajlottak a szülőkkel (22,31\%), 56,15\%-uk osztálytársakkal, barátokkal társalgott először a 
nemi életről. A tanároktól csak 2\% informálódott, amely arra utalhat, hogy az ismeretek közlése késve zajlott, a diákok addigra már más, bár nem feltétlenül hiteles forrásokból gyüjtöttek ismeretet. A diákok 7,69\%-a még senkivel nem társalgott a nemi életről és a védekezésről $(n=130)$. A szülők szerepe az első, nemi élettel kapcsolatos beszélgetésekben elmaradt az egyéb lehetőségekhez képest, a lányok viszont nagyobb arányban beszélgettek erről szüleikkel, mint a fiú kitöltők.

A meglévő ismereteiket nagyobbrészt $(67,57 \%)$ iskolai felvilágosítás kapcsán szerezték a tanulók, közel ilyen arányban jelölték a barátokat, mint forrást (60,14\%), valamint az internet is népszerünek mutatkozott (54,73\%). A szülők szerepe a felvilágosításban az édesanyák esetén 39,19\%-nál, az édesapák vonatkozásában csupán 20,27\%-nál jelentkezett ( $n=148)$. A fiúk internetes ismeretszerzése meghaladta a lányokét $(\mathrm{p}=0,00001)$. Az édesanyáktól, barátoktól és iskolai felvilágításból szerzett ismeretek viszont a lányok esetén domináltak.

A felmerülő kérdéseire az interneten keres választ a tanulók közel harmada $(36,54 \%)$, illetve baráti körben vitatja meg azokat (27,88\%). Az édesanyját csak minden 5. tanuló kérdezi (19,23\%), a tanárokhoz viszont egy diák sem fordul a kérdéseivel. A fiúk gyakrabban keresnek az interneten, a lányok inkább barátaikkal vitatják meg kérdéseiket. A fiúk 61,43\%-a, míg a lányok 41,03\%-a keresett már fel valaha kifejezetten felvilágosító weboldalt az interneten.

Az eredmények alapján a tanulók nagyobb aránya $(30,61 \%)$ nem mindent mer megbeszélni a szüleivel a szexuális élettel kapcsolatban, a csoport negyede viszont $(25,85 \%)$ olyannyira kellemetlennek érzi a helyzetet, hogy sosem fordul szüleihez e kérdésben. Hasonló arányban voltak azok, akik a kellemetlenség ellenére kérdeznek, viszont csupán 19,05\% vallotta, hogy nyíltan tud beszélni a „kínos” témákról otthon (n=147).

A fiatalok közel fele nyilatkozott arról $(43,24 \%)$, hogy nehezére esik beszélni a szexualitásról, megfogalmazódnak benne kérdések, de gyakran nem meri öket feltenni ( $\mathrm{n}=148)$.

A szülőkkel zajló kommunikáció tehát sokesetben kellemetlenséget okoz. Felmerült a kérdés, hogy ez összhangban van-e a szülök válaszadás alól való kitérésével. A khí-négyzet-próba és a gyakorisági táblázat szerint szignifikáns kapcsolat van a két tényező között $(\mathrm{p}=0,034)$. Akik mindent nyíltan meg tudnak beszélni otthon, azoknak szüleire nem jellemző az adott témában zajló beszélgetés kerülése. Aki nem mer mindent megbeszélni, annak családjában már felfedezhető némi visszautasítás, de többségében még mindig vállalták a válaszadást. Akik a kellemetlenség ellenére mégis kérdeznek otthon, szintén kevésbé tapasztalnak hárító magatartást a szülők felöl. Akik viszont sosem kérdezik szüleiket, kitéréssel sem szembesültek még, bár ennek oka lehet, hogy nem is fordulnak szüleikhez a kérdéseikkel [9].

\subsubsection{A szexuális védekezéssel kapcsolatos ismeretek}

A fogamzásgátlással kapcsolatos kérdések alapján látható volt, hogy a gumióvszer és a fogamzásgátló tabletta voltak a legismertebbek a diákok körében. A megszakított közösülést (76\%) és a hüvelybe helyezhető eszközöket $(72,67 \%)$ a csoport közel háromnegyede ismerte, a méhen belüli eszközökröl azonban kevesebb, mint harmaduk hallott (30\%). Injekciós megoldásról $(20,67 \%)$ és spermicidölö szerekről a diákok ötöde rendelkezett ismerettel $(19,33 \%)(\mathrm{n}=150)$.

Leggyakoribb információforrásként ismét az iskolai felvilágosítás $(75,84 \%)$ és az internet $(72,48 \%)$ szerepeltek. A tv-reklámok $(44,3 \%)$ és a barátok (46,98\%) az esetek kevesebb, mint felénél szolgáltattak új ismeretet. A szülők ismét háttérbe szorultak, az édesanyákat azonban még így is több mint kétszer annyian jelölték (40,94\%), mint az édesapákat $(17,45 \%)(n=149)$.

A fiatalok elsöprő többsége vélte úgy, hogy a gumióvszer alkalmas a szexuális úton terjedő betegségek kivédésére $(96,62 \%)$, azonban megközelítőleg minden 10. diák azt is gondolta, hogy a fogamzásgátló tabletta is megfelel erre a célra $(11,49 \%)$. A fiúk esetén nagyobb arányú volt az utóbbi 
gondolat (12 fö), mint a lányoknál (5 fö). 5-8 fö kivételével a diákok nem bíztak a megszakított közösülés, a méhen belüli eszközök és az injekció nemi betegséget kivédő hatásában ( $n=148)$.

A fertőző nemi betegségek terjedése esetén a hüvelyi úton fertőződést $95,92 \%$ gondolta valósnak, viszont a diákok közel harmada az orális terjedést is jelölte (37,41\%). Közel ennyien (föként a lányok) a közös illemhely használatot is veszélyforrásnak tartották (34,01\%). A vérrel történő terjedés a diákok kétharmada szerint lehetséges $(65,31 \%)(\mathrm{n}=147)$ [9].

\subsubsection{A tájékozottság értékelése a védekezéssel kapcsolatos kérdések tükrében}

A kérdésekre adott válaszok alapján a fiúk kétharmada megfelelő vagy elfogadható, negyede hiányos, 7 fó azonban nagyon hiányos tudással bírt a védekezés terén $(\mathrm{n}=71)$ (1. ábra). A lányoknak csupán kicsit több mint fele esett a legjobb ismerettel rendelkező kategóriába, harmaduk hiányosan informált volt, szintén 7 fó pedig kifejezetten hiányos tudással rendelkezett $(n=76)$ (1. ábra). A tájékozottság szubjektív értékelése szerint $93 \%$ gondolta magáról, hogy megfelelö ismeretekkel rendelkezik, azonban az összesítés alapján a kitöltők közel $40 \%$-ánál hiányos volt a védekezéssel kapcsolatos tudás.

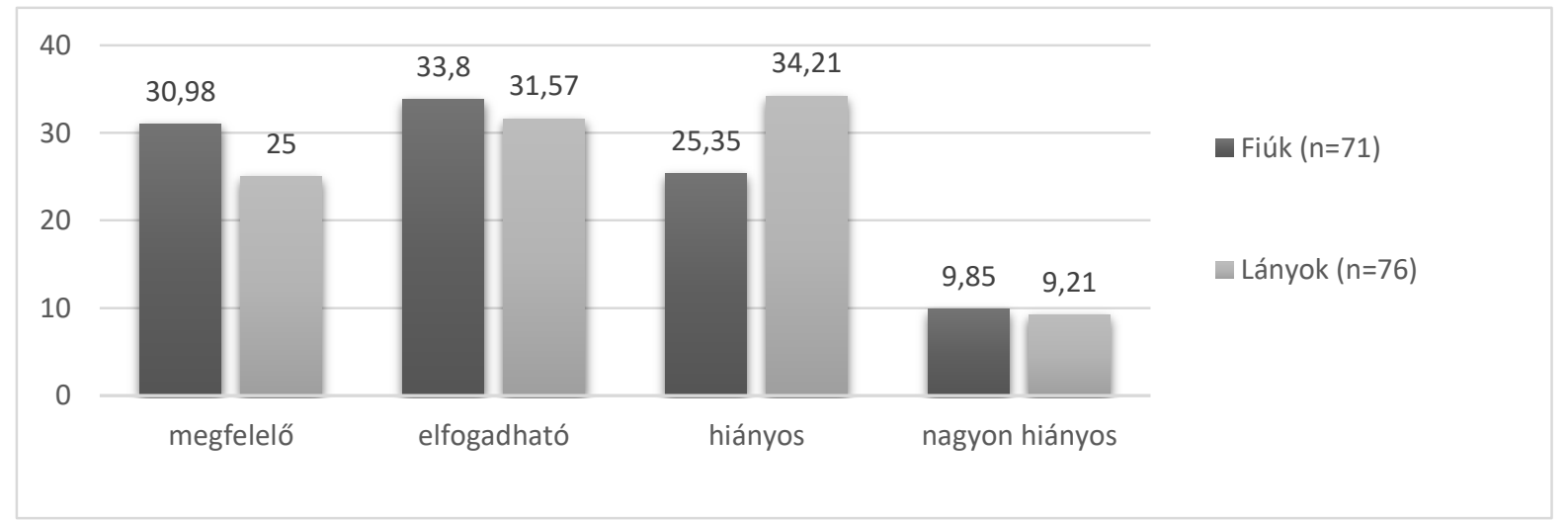

1. ábra. A védekezéssel kapcsolatos tájékozottság alapján felállitott kategóriák százalékos megoszlása a nemek viszonylatában.

Forrás: saját szerkesztés.

Statisztikailag kimutatható kapcsolat volt a diákok tájékozottsága és nemi életük megkezdési ideje között. A kielégítőbb tudással rendelkezők nagyobbrészt még nem kezdték meg szexuális életüket $(\mathrm{p}=0,041)$. A fiatalok nemi élettel kapcsolatos tájékozottsága összefüggést mutatott az anyagi helyzetükkel is $(\mathrm{p}=0,005)$. Az anyagilag elönyös helyzetben élök többségének elfogadható vagy megfelelő volt a tudása, azonban a nélkülözések között élöknél gyakoribb volt a hiányos ismeret, bár ebbe a kategóriába kevesek tartoztak [9].

\section{Következtetések és javaslatok}

A szexualitás témaköre már a 10-12 éves gyermekek beszélgetéseiben megjelenik, így a beavatkozás optimális ideje az általános iskolai felső tagozat kezdete. A szakirodalmi gondolat szerint a túl korai felvilágosítás hátránya kisebb, mint a megkésett kommunikáció hozadéka [7]. Az ismeretátadás alkalmazandó módja a spirális oktatásszervezési forma, melyben adott időközönként visszatérnek az ismeretek, de egyre magasabb szinten, mindig a korosztályhoz illeszkedően. Célszerü az elrettentés kerülése a kommunikáció során, hiszen a gátlások, félelmek elültetése nem kedvez az egészséges szexuális kultúra kialakulásának. A diákok felé közvetített tényszerü ismereteken túl a 
beszélgetésekben sor kerülhet a szerelemmel, a harmonikus párkapcsolattal és az intimitással kapcsolatos témákra, mint az egészséges nemi élet lelki ,alapkövére”.

Tekintve, hogy a fiatalok szívesebben beszélik meg kortársaikkal a „kínos kérdéseket” (84,29\%; $\mathrm{n}=140$ ), az egészségfejlesztésben alkalmazott kortárshatás alkalmazható lehetne a szexedukációban. A középfokú oktatás, illetve az egészségügyi ágazati iskolák tanulói az egészségügyi tanárok vezetésével és felkészítése mellett bekapcsolódhatnának az órák levezetésébe.

A szexualitással kapcsolatos, kellemetlennek érzett kérdések feltételére, így a félelmek és téves gondolatok eloszlatására alkalmazható lehet a kérdésláda, majd a kérdések csoportos megbeszélése, így a szemérmesebb diákok anonim módon, bátran kérdezhetnek. A szintén anonim kérdőívek válaszai segíthetik az egészségügyi tanárok munkáját, hiszen fény derülhet a tanulói ismeretek hiányosságaira, így az órák felépítésekor beilleszthetők olyan elemek, amelyek célzottan illeszkednek az adott csoport igényeihez, tudásához.

A szexualitással kapcsolatos kommunikáció is fejlesztendő, hiszen sok esetben a kérdés megfogalmazás nehézsége és a téma tabuként kezelése gátolja a hiteles, oktatóktól nyerhető információk szerzését. A szakirodalmi és a kutatási adatok is megmutatták, hogy a szülőkhöz kevés fiatal fordul kérdéseivel, pedig az egészséges nemi kultúra megalapozásában fontos a családon belüli biztonságot adó bizalmi viszony megléte. Az egészségügyi tanárok feladatának része lehet a szülők figyelmének felkeltése és az „oktatás” is. A szülők kommunikációs stratégiáinak fejlesztése épp olyan fontos, mint a diákok ilyen irányú nevelése. Szülői értekezleteken vagy tematikus programokon megjelenhet az említett probléma és annak hangsúlyozása, hogy az adott helyzetben kínos beszélgetés a gyermekkel hosszútávon kiküszöbölheti a más forrásból származó torz információk következményeit (nem kívánt terhesség, önértékelési problémák, stb.) [9].

\section{6. Összefoglalás}

A vizsgált diákok többségének volt már része párkapcsolatban, viszont a csoport nagyobb része még nem kezdte meg nemi életét, azonban akik igen, a középiskolai tanulmányok első felében élték át első élményeiket. A védekezési magatartás a diákok harmadánál nem feltétlenül volt kielégítő és - föleg a fogamzásgátlási módok tekintetében - az ismeretek terén is mutatkoztak hiányosságok, noha ezt a tanulók tájékozottságukról alkotott szubjektív véleménye nem tükrözte. Kifejezetten korai életkorban hallottak először a nemi életről, a szülők, föleg az édesapák szerepe a felvilágosításban azonban messze alulmaradt a többi lehetőséggel és a médiával szemben. A fiatalok csekély százaléka tud csak nyíltan kommunikálni otthon a szexualitással kapcsolatban, amely nem kedvez az egészséges nemi kultúra kialakulásának.

Az egészségügyi tanárok szerepe az attitüdformálásban rejlik. Ez optimálisan egy folyamatos tevékenység, amely figyelmet fordít az életkori sajátosságokra és az adott életszakaszhoz tartozó változások érzékenységére. Az egészségügyi tudásukat immár oktatásmódszertani ismereteikkel kiegészítve az egészségügyi tanárok hatékony résztvevői lehetnek a diákok egészségtudatos személyiségformálásának.

\section{Köszönetnyilvánítás}

A cikkben ismertetett kutató munka az EFOP-3.6.1-16-2016-00011 jelü „Fiatalodó és Megújuló Egyetem - Innovatív Tudásváros - a Miskolci Egyetem intelligens szakosodást szolgáló intézményi fejlesztése" projekt részeként - a Széchenyi 2020 keretében - az Európai Unió támogatásával, az Európai Szociális Alap társfinanszírozásával valósul meg. 


\section{Irodalom}

[1] KSH: Magyarország, 2016. (2017) http://www.ksh.hu/docs/hun/xftp/idoszaki/ mo/mo2016.pdf (letöltés: 2018. 09. 09.)

[2] Népesség, népmozgalom (1941-) http://www.ksh.hu/docs/hun/xstadat/xstadat_eves/i_wnt001c.html (letöltés: 2021.01.06.)

[3] Kapitány, B., Spéder, Zs.: Gyermekvállalás, In Monostori, J., Öri, P., Spéder, Zs. (szerk), Demográfiai portré, Budapest: KSH Népesség-tudományi Kutatóintézet, (2015) pp. 41-56.

[4] Ruzsicska, Y.: Gyermekvállalási szokások újabb kori változásának hatásai Magyarországon, különös tekintettel a nöi reproduktiv életszakasz extrém végpontjaira, (2014) pp. 84-108. http://doktori.bibl.u-szeged.hu/2115/13/Ruzsicska_Yvette_ Ph.D._Disszertacio.pdf (letöltés: 2018. 09. 11.)

[5] Jäger, A., Tigyiné Pusztafalvi, H.: Szexuális magatartás vizsgálat középiskolások körében, Egészség-Akadémia, 4 (1) (2013) pp. 50-58.

https://www.researchgate.net/profile/Henriette_Pusztafalvi/publication/292606821_Szexualis_ magatartas_vizsgalat_kozepiskolasok_koreben/links/56afa0ad08ae9f0ff7

b26d42/Szexualismagatartas-vizsgalat-koezepiskolasok-koereben.pdf (letöltés: 2018. 03. 11.)

[6] Makay, Zs.: Párkapcsolati magatartás és gyermekvállalás a fiatalok körében, Magyar Ifjúság 2012, (2013) pp. 53-89.

[7] Szilágyi, V.: Vezérfonal az intézményes szexuális neveléshez, A „Magán-életi kultúra -korszerü életvezetés" Alapítvány kiadványa, Magyar Szexológiai Szemle 2000. évi különszáma, (2000) http://www.sexarchive.info/Magyarul/Nyito_oldal/Online_Koenyvtar/Koenyvek/Vezerfonal.ht m\#\#bev (letöltés: 2018. 09. 11.)

[8] Huszti, É., Takács, P., Hüse L.: A „Nyíregyháza Ifjúsága 2015” kutatás módszertana, Acta Medicina et Sociologica - Vol 7., Debreceni Egyetem Egészségügyi Kar, Nyíregyháza (2016) pp. 219-256.

https://dea.lib.unideb.hu/dea/bitstream/handle/2437/222008/file_up_A\%20Ny\%C3\%ADregyh \% $3 \%$ A 1 za\%20Ifj\%C3\%BAs\%C3\%A1ga\%202015\%20kutat\%C3\%A1s\%20m\%C3\%B3dszer tana.pdf?sequence $=1 \&$ isAllowed=y (letöltés: 2018.09 .10 .)

https://doi.org/10.19055/ams.2016.7/20-21/11

[9] Kiss-Kondás, D., Rusinné Fedor, A., Kiss-Tóth, E.: Középiskolás diákok szexuális magatartásának és tájékozottságának vizsgálata, Egészségtudományi Közlemények, 8. kötet, 2. szám (2018) pp. 19-32. 